UDC 327::911.3(262)

DOI: https://doi.org/10.18485/iipe_ria.2020.71.1179.4

Biblid 0543-3657, 71 (2020)

Vol. LXXI, No. 1179, pp. 77-92

review paper

\title{
CHALLENGES AND ACHIEVEMENTS OF INTEGRATION PROCESSES IN AFRICA IN LIGHT OF THE NEW CONTINENTAL FREE TRADE AGREEMENT
}

\author{
Danilo BABIĆ ${ }^{1}$
}

\begin{abstract}
Ever since the African states regained their independence in the second half of the twentieth century, there has been an idea among African political elites about mutual cooperation among their independent states. The spirit of Pan-Africanism was a mainstream discourse within African political, intellectual, and cultural elites throughout the twentieth century. The Pan-African idea was soon concretized into the Organization of African Unity, which was replaced in 2002 by the African Union as we know it today. Yet, despite numerous initiatives, monetary unions, regional economic committees, and the establishment of the African Union as an umbrella organization, the effects of African integration were not good enough. The African Union did not have the strength to impose common policies on all its members, funding remained a permanent problem, and regional economic committees were suffering from the "spaghetti bowl effect" caused by numerous overlaps in membership. Perhaps the biggest problem lies in the fact that African citizens have not been able to feel the benefits of integration, despite sporadic improvements in macroeconomic indicators. New momentum in African integration happened in the spring of 2018 with the launch of a new initiative called the African Continental Free Trade Agreement - AfCFTA. The new agreement differs from the previous agreements in the number of signatories. It has been signed by all countries of the continent (except Eritrea), and it has already been ratified by most of them. The agreement has clear implementation strategies and evaluation criteria. However, we must reexamine whether the new agreement will succeed in overcoming the obstacles that have dulled previous regional initiatives and whether it will succeed in overcoming new obstacles that will emerge in the future.
\end{abstract}

Keywords: AfCFTA, African Union, integration, free trade.

\footnotetext{
${ }^{1}$ Research Assistant, Institute of International Politics and Economics, Makedonska 25, Beograd, danilo.babic@diplomacy.bg.ac.rs
}

The paper presents findings of a study developed as a part of the research project "Serbia and challenges in international relations in 2020", financed by the Ministry of Education, Science, and Technological Development of the Republic of Serbia, and conducted by the Institute of International Politics and Economics, Belgrade. 


\section{INTRODUCTION}

There has been an idea among African political elites about mutual cooperation among their independent states ever since the African states regained their independence in the second half of the twentieth century. The idea was long-planned, and the first significant and official document was the Abuja Agreement, signed in 1991. Yet, despite numerous initiatives, the effects of African integration were not good enough. In 2018 and 2019, a new comprehensive regional initiative emerged in Africa - the African Continental Free Trade Area (AfCFTA). In this paper, we seek to identify and analyze the factors that will affect the implementation of this agreement and to shed light on its future. We first begin by analyzing the importance of regional integration for economic performance. Then we discuss the present structure of African regional structures on which the AfCFTA agreement should be implemented. Finally, we discuss the agreement itself: the framework and goals of the agreement, the expected benefits and challenges that have already occurred and will occur in the future of the implementation process.

\section{THE IMPORTANCE OF REGIONALISM FOR THE ECONOMY - BROAD OVERVIEW}

Traders and businessmen have always strived for regional integration in order to expand their markets. The first regional trade bloc worth mentioning was the mighty Hanseatic League, which was the most important European trade organization from the thirteenth to the first half of the fifteenth century. After the collapse of the Hanseatic League, the idea of regional integration experienced its revival in the second half of the 20th century. In the period after the Second World War, there has been a growing interest in integrating national economies at regional levels, and regionalism has become the mainstream of European political thought. However, it is interesting to mention that the first modern regional economic integration took place in Africa in 1910 with the formation of the Southern African Customs Union (SACU). It was established by an independent Boer colony and British colonies (present-day countries of Botswana, Lesotho, Namibia, Eswatini, ${ }^{2}$ and South Africa). (Mwhasa 2007, p. 9).

We can identify trade, development, political stability, and security as the main motives for economic integration in developing countries in general that can be said for African countries as well (Pangestu, Scollay 2001, pp. 4-6).

Generally, the benefits of economic integration are larger markets, greater competition, and the realization of economies of scale (Hoekman et al., 2002).

\footnotetext{
${ }^{2}$ Former Swaziland, changed its name on 19 April 2018. (Times of Swaziland 18.05.2018.)
} 
Regional economic groups eliminate or reduce trade tariffs and other non-tariff barriers (NTB) (Mwhasa 2007, p. 2). Free trade is expected to lead to a rapid increase in trade volume, which would likely lead to rapid economic growth. These gains result from the dynamic effects of integration, which are cumulative in nature and lead to growth. Thus, the contribution of regional economic integration to economic growth will be greater if there are economies of scale, which is made possible by increased market size (Yang, Gupta, 2005, pp. 22-24).

Economic integration can only enhance growth if it promotes investment in both physical and human capital. According to Todaro and Smith, developing countries should go beyond greater trade with one another and move in the direction of economic integration (Todaro, Smith, 2015: 650). Increased investment is likely to encourage multinational corporations to invest and produce within the integrated economies to avoid trade restrictions imposed on nonmember states. Regional economic integration can serve a useful economic purpose beyond the direct gains from trade liberalization, by reducing uncertainties and improving credibility and thus making it easier for the private sector to plan and invest. In order to reduce uncertainties and improve the credibility of the regional integration endeavor, Fernandez lists several activities and mechanisms that should be implemented. The first two activities are: good signaling to the investors and providing them with good insurance for their investments. The third mechanism (rather than the activity) is bargaining power with third countries that comes naturally with the membership in a regional block. The fourth is a coordination mechanism available within the regional bloc that allows an even distribution of gains from regional integration (Fernandez, 1997, pp. 15-20).

In relation to political aspects, many regional economic communities have been driven by political rather than economic goals. These political objectives include, among others, security, governance, democracy, and human rights (Hoekman et al. 2002). The recent Sahel G5 initiative is a good example to prove this point.

As concluded by Todaro and Smith, the developing countries at approximate stages of industrial development with similar market sizes and a strong interest to rationalize their joint industrial growth patterns stand to benefit from the combined inward and outward-looking economic integration. They continue to argue that regional groupings of small nations like those of Africa can create the economic conditions for accelerating their joint development effort and also encourage development in the long-run. For this reason, economic integration should be seen as a means to promote a balanced division of labor among a group of countries, each of which is too small to benefit from such a division of labor by itself. In fact, without integration, each individual country may not provide enough domestic market size and potential to achieve economies of scale (Todaro and Smith 2015). 
All the authors mentioned so far talk about the positive effects of economic integration such as trade creation, GDP and investment growth, but there is a negative side to it as well. Jacob Viner, although a proponent of free trade, points out that the process of trade creation and trade diversion occurs simultaneously because several member countries (of any FTA) will be trading concurrently with different members and nonmember countries (Viner 1950). Moreover, there are no guarantees that countries will use their comparative advantages better just because they are integrating.

When we analyze the situation in Africa in particular, we can see a few more negative aspects of economic integration and regionalism. Firstly, Fredrik Söderbaum points out that imitating the EU's institutional design will not be suitable for the African social context (Söderbaum 2014). Secondly, Morten Bøas states that many political leaders in Africa engage in symbolic and discursive activities - praising the goals of regionalism and regional organizations, signing cooperation treaties and agreements just as an image-boosting exercise for themselves. They are taking part in "summitry regionalism" as Bøas calls it while remaining uncommitted to the jointly agreed policies. Some leaders show demonstrative support and loyalty towards one another in order to raise the status, image and formal sovereignty of their often-authoritarian regimes, both domestically and internationally (Bøas et al. 2005). Jeffrey Herbst also agrees with this claim but adds that this misplaced enthusiasm of African leaders should not be interpreted as a failure because even they can do some positive things while trying to boost their image (Herbst 2007). Thirdly, William Reno introduces another concept called "shadow regionalism." Shadow regionalism refers to a particular type of state where corrupt politicians are sheltered by the formal facade of political power based upon informal markets. There is a strong transnational dimension of these informal activities, which can also enhance our understanding of informal regional activities. Building on Reno's concept, "shadow regionalism" suggests that regime actors use their power positions within the state apparatus in order to establish a complex mode of regionalism characterized by informality and the search for personal gain. Shadow regionalism tends to exist in those places where patron-client relationships are the strongest. Reno claims that even a small number of so-called shadow agents may block or even destroy egalitarian forms of development and regional organizations. Hence, shadow activities undermine the regulatory capacity of the state as well as regional organizations. Those who promote it may actively seek to preserve existing boundary disparities (e.g., customs, monetary, fiscal, and normative). Consequently, political leaders who resist formal regionalism may do this as a deliberate strategy to maintain the status quo and avoid disrupting their lucrative activities (Reno 1995). 


\section{STATUS OF INTRA-AFRICAN INTEGRATION IN LIGHT OF THE AFCFTA}

In this section, we analyze the circumstances and the foundations on which the AfCFTA agreement will be implemented. We highlight the macro and microchallenges that will hinder the implementation of the agreement. As macrochallenges, we emphasize the very structure of the current intra-African integration. Other factors, such as the inadequate political and economic system of individual countries as well as security challenges, are considered to be micro-challenges.

The framework for African integration was set up in 1991 when the Treaty (of) establishing the African Economic Community was signed (the treaty is better known as the Abuja Treaty). The Abuja Treaty set out the vision of African financial and monetary integration in the six-phase treaty. After an African common market was established, an African monetary union was to be realized through the creation of a single African central bank and a single African currency. The vision saw the continent moving from a common market towards a monetary union. In practice, this has not happened (yet) (ARIA IX 2019, p. 2). The Abuja Treaty enabled the creation of eight regional economic communities $(\text { RECs })^{3}$ which are the pillars of African integration until this day. Yet these RECs have many shortcomings, the largest of which is overlapping membership, also known as the "spaghetti bowl effect". Kenya is an absolute champion with membership in as many as four communities (CEN-SAD, COMESA, EAC, and IGAD). Only twelve African countries belong to a single REC; thirty-three of them belong to two RECs, and eight countries belong to three RECs (ARII Report 2016, p. 13).

Although they have similar objectives, the RECs were established independently and differ in both structure and activity. Consequently, this has led to a different level of internal integration within different RECs. Some have achieved tangible outcomes in key areas of integration, while others struggled to meet even the basic form of integration. Several RECs have moved individually towards financial and monetary union, while others have not. (ARIA IX 2019, p. 2). Three monetary unions are currently operating in Africa — the West African CFA franc, covering

\footnotetext{
${ }^{3}$ There are eight regional communities: CEN-SAD, COMESA, EAC, ECCAS, ECOWAS, IGAD, SADC and UMA (ARII Report 2016, p. 13).

${ }^{4}$ The Spaghetti bawl effect is the term coined by Jagdish Bhagwati, professor of economics and law at Columbia University. He claims that FTAs are paradoxically counter-productive in promoting free trade. According to Bhagwati, too many overlapping FTAs would allow countries to adopt discriminatory trade policies and reduce the economic benefits of trade. The Spaghetti bawl effect enables discriminatory trade policy because the same commodity is submitted to different tariffs in various domestic trade systems due to their difference in preferences. Among Asian nations, the effect is also known as the "noodle bowl effect" (Bhagwati 1995 p. 4).
} 
most francophone countries in West Africa; the Central African CFA franc, covering six countries of Central Africa, and the Common Monetary Area, linking Eswatini, Lesotho, Namibia, and South Africa. None of the monetary unions is conterminous with any of the eight RECs - each of the monetary unions is an isolated island of deeper integration within one of the RECs.

Five of eight RECs have set macroeconomic and monetary convergence targets in order to reduce the difference in the integration among the RECs. But these convergence criteria differ from one REC to another. An additional problem is that the member countries within these RECs have not converged enough. (ARIA IX 2019, pp. 2-3).

When we look at some of the RECs individually, we can clearly see the difference in convergence criteria. The Southern African Development Community (SADC) utilizes budget deficit average, annual inflation and public debt-to-GDP ratio, Central Bank financing of budget deficits, and an exchange rate volatility as convergence criteria. Moreover, the SADC aimed for a common market by 2015 , a monetary union by 2016 , and a single currency by 2018 . These targets proved to be overly ambitious.

The EAC uses average annual inflation, FX reserves, fiscal deficit, and public debt as indicators. The EAC is the most advanced REC in regional integration. Unlike the SADC, the EAC countries were successful in establishing a common market in January 2010. Member states of this REC made constant progress in implementing common standards, rules of origin, and a common external tariff and completely eliminating internal tariffs (ARIA IX 2019, p. 6).

The Economic Community of West African States (ECOWAS) focused on creating a monetary union. The ECOWAS convergence criteria were realigned in 2014 to pursue merging the West African Monetary Zone and the West African Economic and Monetary Union (WAEMU) countries into a single monetary zone by the beginning of 2020. (ARIA IX 2019, p. 3). The creation of a new currency named Eco that will partly replace the CFA franc is planned for 2020.

Infrastructure, peace and security and political factors are perceived as microchallenges. Adequate infrastructure is the key driver of economic growth and sustainable development across the African continent. Furthermore, infrastructure is the key factor that facilitates regional integration as well. It enables export-oriented companies to access regional (and international) markets quickly, cheaply, and efficiently. Unfortunately, this key factor is missing in Africa. For example, road density in Africa is only a quarter of the world average (Mafusire and others, 2010; African Energy Forum, 2016). Only 25\% of the continent's road network is paved, while the world average exceeds 50\% (ARIA IX 2019, p. 20). There are nine highways across the continent with a total length of 56,683 kilometers. (The construction of the tenth is planned.) Many sections of these 
highways are not completed or have been significantly damaged; even their maintenance is a serious problem. The lack of access roads and local interconnections makes the Trans-African Highway Network rather a more beautiful vision of the future than a significant infrastructure network in the present. The situation is similar regarding the railway network that is outdated and not standardized in all parts of the continent. These are mostly rails from the colonial times. In an area of 29.6 million $\mathrm{km}^{2}$, there is only $89,000 \mathrm{~km}$ of the railway, which means a density of $2.5 \mathrm{~km}$ per $1,000 \mathrm{~km}^{2}$. For comparison, the rail network density in Europe is $40 \mathrm{~km}$ per $1,000 \mathrm{~km}^{2}$ (International Union of Railways Synopsis 2012; AU-web site).

Air traffic is also underdeveloped. It mainly takes place from three major centers: Johannesburg, Nairobi, and Addis Ababa. From almost any African country, it is easier to find a connection with the former colonial metropolis than with another African country. Sometimes an absurd situation occurs that a connection between the two African countries takes place via London or Paris. For that reason, the Air Transport Market (SAATM) is a flagship project under Agenda $2063^{5}$. The goal is to liberalize and unify "the African skies". Thus far twenty-three countries signed the agreement, but the map of united African skies has a big barrier in the middle of the continent because Rwanda is the only Central African country that signed the Treaty. This project facilitates the free movement of people and goods, enhances the continent's integration and connectivity and fosters tourism and trade. It will definitely reduce ticket prices and facilitate the development of intra-continental tourism. Moreover, this will positively affect the idea of African Union passport which is in its inception. It is expected to support the Action Plan for Boosting Intra-African Trade and the AfCFTA. The AU Commission estimates that this deal will generate up to 300,000 direct and up to 2 million indirect jobs. (ARIA IX 2019, p. 22) Therefore, we can conclude that insufficient investment in infrastructure constrains the African countries' ability to fully profit from the growth and job creation opportunities that will arise from the AfCFTA (ARIA IX 2019, p. 18). However, positive impulses are emerging: infrastructure development in Africa reached $\$ 81.6$ billion in 2017, which is an increase of 22\% from 2016. (ARIA IX 2019, p. 23).

Although in poor condition, African infrastructure has not been neglected. Contrary to popular belief, intra-African investments in infrastructure are not

\footnotetext{
${ }^{5}$ AGENDA 2063 is an African strategy for transforming Africa into the global powerhouse of the future. The goal is to reach inclusive and sustainable development. The agenda is defined by ten structural programs covering different areas, from infrastructure projects to the preservation of cultural, intangible heritage. The AfCFTA is included in the Agenda as the third pillar (African Union web site).
} 
insignificant. During the period 2013-2019, it amounted to $\$ 80-90$ billion annually (ARIA IX 2019, p. 25).

Peace and security are the second micro-challenge that we analyze. Peace and security are necessary conditions for pursuing regional integration. Including the AfCFTA, the African Peace and Security Architecture (APSA) is a core component of the AU Peace and Security Council, and it is the AU's central institution for preventing, managing, and resolving conflicts. (Khadiagala, 2018, p. 5). We can identify three types of security challenges in Africa: inter-communal violence and civil war, terrorism, and smuggling. Each of them represents a serious challenge to the regional integrations initiative, the AfCFTA included. In countries affected by the civil war, we can always question the legitimacy of the government signing the agreement. That can undermine the implementation of the AfCFTA in the long run. As for terrorism - although a threat - it paradoxically represents an opportunity for regional cooperation. That is the case with the Sahel G5 initiative ${ }^{6}$ where five countries combined their forces in order to combat ISIS-related groups in the region. They are moving towards creating an integrated defiance system while strengthening their individual armies in the process. Smuggling is easily enforceable in Africa because of porous borders that are not well secured due to the inaccessible terrain and modest security capacities of most African countries. This criminal activity can hinder the economic benefits of integration due to contraband.

The last of the micro-challenges are political factors. Besides the usual fear of sovereignty loss (that always arises when it comes to regional integration), we should not neglect rivalries that may arise between some countries in the long run, such as Ethiopia versus Egypt, or the Republic of South Africa versus the rest. There is also the "Nigeria factor". Nigeria reluctantly signed the Treaty and has not ratified it yet. As one of the strongest economies in the continent, Nigeria's government is concerned that the AfCFTA will weaken Nigeria's position. Therefore, there is a possibility that Nigeria would act as a Trojan horse and try to sabotage the AfCFTA or sway it in its favor in order to maintain its own dominant position.

\section{AFRICAN CONTINENTAL FREE TRADE AGREEMENT}

\section{Framework of the agreement}

The AfCFTA agreement has three layers. The first layer is a framework agreement that defines general terms, the purposes and intentions of the

\footnotetext{
${ }^{6}$ Members of the Sahel G5 initiative are Burkina Faso, Mauritania, Mali, Niger, and Chad.
} 
agreement, establishes its primary definitions and outlines its scope. The framework agreement also creates the institutional framework for implementing the AfCFTA. Moreover, this layer relates the agreement to other relevant international and regional treaties and agreements.

The second layer comprises the protocols of the agreement, which cover trade in goods, trade in services, rules and procedures for the settlement of disputes, investment, competition policy, and intellectual property rights.

The third layer contains the annexes, lists, and schedules to the protocols. The purpose of this is to articulate the provisions of the protocols in detail (ARIA IX 2019, p. 43).

The implementation of the agreement is divided into two phases. Phase I is divided into three sectors (which is comprised of layer two), each of these sectors is covered by a special annex to the protocol (which is comprised of layer three). They are the following:

1) The Protocol on Trade in Goods, which covers customs and administrative cooperation, cooperation in the field of transit trade, technical and (Phyto)sanitary standards, the establishment of integrated customs controls (negotiations are still ongoing) and rules on identification product's country of origin (negotiations are still ongoing).

2) The protocol on the exchange of services. This protocol covers three segments which are Most Favorable Nation (MFN) exemption policies, an annex of air transport, and schedules of specific commitments in services related to the MFN. The last one is still being negotiated.

3) Protocol on the settlement of disputes

Phase II negotiations started in February 2020, its structure has already been drafted. It consists of three sectors: 1) protocol on competition policy, 2) protocol on intellectual property, 3) protocol on investment.

The key negotiating principle of the AfCFTA is to build on and improve the legislative of the existing REC free trade agreements but not reverse what had been agreed previously. This is regulated by article 19 of the AfCFTA agreement that defines the relationship among the AfCFTA and Africa's pre-existing free trade agreements. In any conflict cases among the AfCFTA and RECs, the AfCFTA is to prevail, but with one crucial caveat: if the RECs have achieved greater levels of integration among themselves than it is prescribed by the AfCFTA, the AfCFTA will not reverse what has already been achieved (AfCFTA Agreement Article 19). 


\section{Expected benefits and future goals}

On 30 May 2019, the AfCFTA became officially effective, having more than 22 states that ratified the Treaty (Golubski 01.06.2019). Implementing the AfCFTA is not just about trade. It is more than that, it is about dispelling the "fear of failure" embodied in the inability to enforce the AU decisions and initiatives (ARIA IX 2019, p. 1). But certainly, since we are talking about a trade agreement, the biggest expected benefit is the increase in trade volume. The UNECA has predicted the rise of intra-African trade by 15 to $25 \%$, or $\$ 50$ billion to $\$ 70$ billion, by 2040. (Signe, Van de Ven 2019, p. 2)

It is widely known that tariffs are not the main cause that hinders trade. Trade facilitation within the AfCFTA must address non-tariff barriers (NTBs) that burden businesses even more than traditional tariffs. The gains from tariff reductions are little when compared to gains from eliminating NTBs and increasing regulatory collaboration (Vanzetti, Peters and Knebel, 2018). So, the AfCFTA has many provisions to deal with NTBs. Dealing with non-tariff barriers is handled by articles 3-10 of AfCTA Trade in goods protocol, annex 5. It includes, among other things, the use of a common categorization system for NTBs to improve transparency. Moreover, it promotes several new measures such as the establishment of national monitoring committees. They imply cooperation in the field of sanitary and phytosanitary standardization, and implementation of technical regulations, assessment and accreditation methodology. (Compiled annexes 5, 6 and 7)

Informal cross-border trade (ICBT) is another important dimension of intra-African trade as well. ICBT contributes about $30-40 \%$ of total intraregional trade in the SADC region and 40\% in the COMESA region (Nshimbi and Moyo, 2017). In the absence of formal job opportunities, ICBT is crucial for a normal life, particularly for Africa's most vulnerable people, such as women and youth. ICBT has proven more responsive to food crises than formal trade. Because it is largely practiced by the officially unemployed and micro, small and medium enterprises, it is important for strategies of inclusion (ARIA IX 2019, p. 84). Therefore, the goal of the AfCFTA should not be to stop ICBT but to transform it into the legal business through subsidies or other incentives. Even a small flat tax revenue that could be collected from ICBT traders can be a great income for the local economy. At the same time, those traders can get at least some sense of security.

As we mentioned at the beginning of this section, the AfCFTA has a much larger appetite than just trade, the master plan of African integration is for the AfCFTA to outgrow itself and become a single market. A six-step road map has been put in place in order to achieve this goal: 1) the AfCFTA and regional free trade arrangements will serve as propulsion for deeper integration, 2) 
Liberalization of all trade within the AfCFTA, 3) Merger of all of the continent's free trade agreements, 4) The African continental customs union will be formed in order to replace all of the regional ones, 5) The African common market that implies freedom of capital, labor and services will be put in place, 6) At the final stage, the African single market will be formed. This would imply deep economic harmonization, common policies, joint cohesion funds, etc. Thus far only the first step has been implemented (ARIA IX 2019, p. 55).

\section{Challenges facing the AfCFTA agreement}

Conceptually, a key issue that must be addressed in order to successfully implement the AfCFTA will be how to synchronize the different economic systems of African economies and enable them to work in their common interest. Bearing in mind the huge discrepancy in size, population and resources of these nations, the question is to what extent it is really possible to achieve that.

Operationally, the biggest problem in Phase I had proven to be the Mostfavored nation (MFN) principle. The reason for that is a unique, unorthodox approach to matters concerning MFN. The MFN clause of the AfCFTA does two things:

First of all, it recognizes that the AfCFTA will not immediately equalize with deeper trade liberalizations on the continent. In other words, it will preserve continental preferences, thus allowing the RECs to continue giving each other better treatments than those predicted by the AfCFTA. This is clearly stated in article 18, paragraph 1 of the AfCFTA agreement (AfCFTA Agreement article 18). Therefore, the AfCFTA creates no MFN obligation in the standard sense of the term: state parties may maintain more favorable treatment with the AfCFTA and non-AfCFTA parties without providing them to all AfCFTA parties. Strictly speaking, these provisions should not be named MFN because it is not granting MFN rights to any party. It is rather an exception to MFN than an expression of the principle itself.

Second of all, lack of implementation of the MFN principle in the traditional sense means that principles of conditionality, reciprocity and non-discrimination will not be incorporated. Because of this unique approach, the definition of a third country within the AfCFTA is obscure - it could be either one AfCFTA party alongside others or (more often), a country that is not a party to the AfCFTA. It remains unclear how a clause aimed at creating equality in treatment among parties to an agreement can have conditions that could lead to discrimination.

Furthermore, the unorthodox MFN approach also creates various classes of the AfCFTA parties with various levels of rights within the AfCFTA — most 
of whom would face discrimination if they cannot reciprocate the better treatment accorded to third countries. So although this provision was clearly seeking to prevent any outlaw actions, it will probably complicate the AfCFTA market place rather than consolidating it (ARIA IX 2019, p. 54). As mentioned above, this absence could result in situations where products from third parties imported into African countries are treated more favorably than the same products imported from African countries to other African countries. These problems became apparent during the Phase I negotiations. The lack of a traditional MFN also risks the creation of a patchwork of rights and obligations that differ across each of the parties to the Treaty. It means that the AfCFTA may not promote intra-African value chains to the degree policymakers would wish. Moreover, the absence of a traditional MFN clause could be a significant problem for the remaining $10 \%$ of tariffs, which are not subject to immediate and full liberalization. The faith of the remaining tariffs is still to be determined by the state parties in the ongoing negotiations. The extent to which a lack of a level playing field for African products will hinder intra-African trade will depend on which products are included in the $10 \%$ not immediately subject to liberalization. While most of the ongoing AfCFTA debate on schedules focus on tariffs, it is vital not to forget the sector of services. Not only do services make a significant contribution to manufacturing value chains, but they will also play a key role in intra-African integration and the future of continental trade (Signe, Van de Ven, 2019, pp. 4-5). Commitments in services and the remaining 10\% of products that will remain under tariffs are still being negotiated in Phase I.

Since there are no concrete results of Phase II, we need to anticipate the problems that might arise. As we said, Phase II negotiations focus on competition protocols, intellectual property, and investment. Multiple dilemmas occur regarding objectives of these protocols: should they be conservative or liberal, centralized, or autonomous. In the case of the African Investment Protocol, should the objective be to provide market access to foreign investors, or rather, promote and facilitate grassroots investment? Similarly, regarding the Protocol on Competition, is it better to create the regional intra-African competition super authority or promote the creation of the national competition authorities' network? Finally, should the Intellectual Property Protocol seek to harmonize the variety of overlapping regional and national intellectual property regimes? Or should it strive to develop an exclusive African protocol that would prioritize on specific issues relevant to Africa, such as the protection of traditional knowledge and cultural heritage? Is it possible to do both? Moreover, the MFN problem mentioned above will affect these sectors as well (Signe, Van de Ven 2019, p. 7).

Last but not the least of the problems that must be addressed is the financing of the entire project. Only a few of AfCFTA countries actually have the budget 
to pay for the technical assistance that the AfCFTA may require. One way to resolve this challenge would be to engage the existing RECs to finance initiatives related to technical support and capacity building, but the question is whether this option is realistic given the fact that the AU itself faces huge funding problems.

\section{CONCLUSION}

It is clear that the AfCFTA is just a transitory phase in the bigger picture of African integration. Nevertheless, the AfCFTA is a big and important step on whose success further course of African integration will depend. The eventual failure of the AfCFTA will likely set back the African integration processes for at least a decade. Moreover, it would seriously damage the credibility of any future local initiatives. Officials of the African Union, in particular, are aware of this and do not want to allow failure. Yet, there are many challenges, both circumstantial and within the Treaty itself. Overlapping membership within the RECs is the most obvious problem that needs to be handled. It remains to be seen how the AfCFTA regulatory bodies will cope with political pressures in the implementation of Phase I. These pressures will inevitably come due to the conflicting national interests. Phase II negotiations will represent a challenge both on the conceptual and practical levels. During these negotiations, policymakers must be careful not to add additional layers of complexity to an existing quagmire of regional agreements. Moreover, the capacity to implement all of these measures (both in Phase I and II) is unknown. It is more based on the belief that African capacities have matured enough to handle such a task than on the actual evidence that the capacity is sufficient. This is an additional reason to keep the solutions simple. It is vital not to favor the trade of goods at the expense of the services sector because Africa's services exports tend to grow faster than merchandise exports.

It is impossible to say whether the AfCFTA will be able to achieve its proclaimed goal of full economic integration, which is unattainable even for the European Union, but the AfCFTA is definitely the first step towards a more united and more independent continent.

\section{REFERENCES}

African Union (2019). Assessing regional integration in Africa (ARIA IX) - Next steps for the African continental free trade area, UNECA-AU,-ADBUNCTD, Addis Abeba, Ethiopia

African Union (2016). Africa Regional Integration Index Report 2016 (ARII Report), UNECA-AU,-ADB, Addis Abeba, Ethiopia 
African Union website - Flagship Projects of Agenda 2063 accessed on 11.02.2020. from: https://au.int/en/agenda2063/flagship-projects

African Union website - TAH network 2063 accessed on 10.02.2020. from: https://au.int/web/sites/default/files/newsevents/workingdocuments/297 36-wd-e_-_tah_annex_i_tah_network.pdf

Agreement establishing the African continental free trade area (AfCFTA Agreement 21. 03. 2018) Retrieved from https://au.int/sites/default/ files/treaties/36437-treaty-consolidated_text_on_cfta_-_en.pdf

Bhagwati, J. (1995). US Trade Policy: The Infatuation with FTAs in: Claude Barfield (ed.), The Dangerous Obsession with Free Trade Areas (pages 23), AEI, 1995.

Compiled annexes to the on the establishment of the continental free trade area (16. 05. 2018.) Retrieved from https://www.tralac.org/documents/ resources/african-union/2163-compiled-annexes-to-the-afcfta-agreementlegally-scrubbed-version-signed-16-may-2018/file.html

Fernandez, R (1997). Returns to Regionalism: An Evaluation of Nontraditional Gains from Regional Trade Agreements, World Bank Policy Research Working Paper No. 1816, New York University - Department of Economics, https://doi.org/ 10.1596/1813-9450-1816

Golubski, C. (2019, June 1, 2019) Africa in the news: AfCFTA enters into force, South Africa and Senegal tackle climate change, and presidents inaugurated in Nigeria and Malawi. Retrieved from https://www.brookings.edu/blog/ africa-in-focus/2019/06/01/africa-in-the-news-afcfta-enters-into-forcesouth-africa-and-senegal-tackle-climate-change-and-presidents-inauguratedin-nigeria-and-malawi/

Herbst, J. (2007), "Crafting regional cooperation in Africa", in Amitav Acharya, AlastairJohnston (eds), Crafting Cooperation. Regional International Institutionsin ComparativePerspective (London: Oxford University Press).

Hoekman, B, Matoo, A, English P. (2002). Development, Trade and the WTO, Washington, USA: The World Bank International Union of Railways (Synopsis 2012) Retrieved from https://www.globalmasstransit.net/ archive.php?id $=17685$

Mwasha, O. (2007). The Benefits of Regional Economic Integration for Developing Countries in Africa: A Case of East African Community (EAC). Korea Review of International Studies, pp. 69-92

Pangestu, M. Scollay, R (2001). Regional Trading Arrangements: Stocktake and Next Steps, Bangkok, Thailand: TPF

Reno, W. (1995), Corruption and State Politics in Sierra Leone (Cambridge: Cambridge University Press). 
Salvatore, D. (2006). International Economics, 8Ed, NY, USA: Willey International Edition

Signe, L. Van de Ven, C. (2019). Keys to success for AfCFTA negotiations. Policy brief Africa Growth Initiative at Brookings

Söderbaum, F. (2014). "What's Wrong with Regional Integration? The Problem of Eurocentrism", SSRN Electronic Journal, DOI: 10.2139/ssrn.2399858

Times of Swaziland (18. 05 2018.) Retrieved from http://www.times.co.sz/news/ 118373-kingdom-of-eswatini-change-now-official.html

Todaro, M. Smith, S. (2015). Economic Development, 12th Ed, , New Jersey: United States: Pearson Education

Yang, Y, Gupta, S. (2005,). Regional Trade Arrangements in Africa: Past Performance and the Way Forward, IMF Working Paper WP/05/36, Retrieved from https://www.imf.org/en/Publications/WP/Issues/2016/12/31/ Regional-Trade-Arrangements-in-Africa-Past-Performance-and-the-WayForward-17971

Viner, J. (1950). The Customs Union Issue; Carnegie Endowment for International Peace: New York, NY, USA, 1950 


\section{IZAZOVI I DOSTIGNUĆA INTEGRACIONIH PROCESA UNUTAR AFRIKE U SVETLU NOVOG KONTINENTALNOG SPORAZUMA O SLOBODNOJ TRGOVINI}

Apstrakt: Od kada su afričke države povratile svoju samostalnost u drugoj polovini dvadesetog veka, među afričkim političkim elitama postoji ideja o povezivanju i saradnji njihovih iznova suverenih država. Duh Pan-Afrikanizma predstavljao je glavni diskurs unutar afričkih polititičkih, intelektualnih i kulturnih elita tokom čitavog dvadesetog veka. Pan-afrička ideja je ubrzo konkretizovana u Organizaciju afričkog jedinstva koja je 2002. zamenjena Afričkom unijom kakvu danas poznajemo. Ipak, uprkos brojnim inicijativama, monetarnim unijama, regionalnim ekonomskim komitetetima i osnivanju Afričke Unije kao krovne organizacije, efekti afričkih integracija nisu bili dovoljno dobri. Afrička Unija nije imala dovoljno snage da nametne zajedničke politike svim svojim članovima, finansiranje je (p)ostalo permanentan problem, a regionalni ekonomski komiteti su se međusobno gušili. Možda i najveći problem leži u činjenici da građani afričkih zemalja nisu mogli da osete korist od integracija, bez obzira na sporadična poboljšanja u makroekonomskim pokazateljima. Novi zamajac u afričkim integracijama dogodio se u proleće 2018. godine pokretanjem nove incijative pod nazivom Afrički kontinentalni sporazum o slobodnoj trgovini -AfCFTA. Novi sporazum razlikuje se od prethodnih po tome što je potpisan od svih država kontinenta (osim Eritreje) i već sada ratifikovan od većine. Sporazum poseduje jasne implementacione strategije i kriterijume vrednovanja. Međutim, ostaje nam da preispitamo da li će novi sporazum uspeti da prevaziđe prepreke koje su umrtvile prethodne regionalne inicijative, i da li će uspeti da prevaziđe nove prepreke koje će se pojaviti u budućnosti.

Ključne reči: AfCFTA, Afrička Unija, integracija, slobodna trgovina.

Received: 26/5/2020

Accepted: $13 / 8 / 2020$ 